Original Research

\title{
Kajian Semiotika Dalam Pernikahan Karakter Virtual Hatsune Miku dan Akihiko Kondo
}

\author{
Guguh Sujatmiko ${ }^{1 *}$ \\ ${ }^{1}$ Program Desain dan Manajemen Produk, Fakultas Industri Kreatif, Universitas Surabaya, Surabaya- \\ Indonesia. \\ * corresponding author: guguh.sujatmiko@staff.ubaya.ac.id
}

\begin{abstract}
Akihiko Kondo and Hatsune Miku's marriage ceremony attracted public attention. The marriage shows an unusual relationship between human and virtual character, the Actual world who got married to the Ideal world. This paper uses a qualitative method of the semiotic theory of Rholand Barthes. This paper_tries to describe the signs that are connected to both virtual characters and humans. The signs were dismantled to find out what codes and symbols that worked. The results show that the signs which were constructed into Hatsune Miku's character have naturalization of meaning, therefore the arose myths became ordinary as humans consume virtual signs continuously and endlessly. The signs become very important, the ideal world will be more interesting to be explored because it provides very broad opportunities in the signs development.
\end{abstract}

Keywords: semiotic, virtual, character

\begin{abstract}
Abstrak-Pernikahan seorang lelaki bernama Akihiko Kondo dan Hatsune Miku cukup menarik perhatian masyarakat. Pernikahan tersebut menunjukkan hubungan yang tidak biasa antara manusia dalam dunia aktual yang menikahi karakter dalam dunia ideal. Penelitian ini menggunakan metode kualitatif dengan pendekatan teori semiotic dari Rholand Barthes. Penulis mencoba menguraikan tanda-tanda yang terhubung antara keduanya. Tanda-tanda tersebut dibongkar untuk mengetahui kode-kode dan simbol-simbol yang bekerja. Hasil menunjukkan bahwa tanda-tanda yang dikonstruksi menjadi karakter Hatsune Miku mengalami naturalisasi makna, sehingga mitos-mitos yang timbul menjadi hal yang biasa karena manusia mengonsumsi tanda virtual terusmenerus dan tiada akhir. Tanda menjadi hal yang sangat penting, dunia ideal akan semakin menarik untuk dieksplorasi karena memberikan kesempatan yang sangat luas dalam perkembangan tanda.
\end{abstract}

Kata kunci: semiotik, virtual, karakter

\section{PENDAHULUAN}

Hatsune Miku merupakan tokoh virtual yang dirilis pada tahun 2007. la dibuat untuk dapat bernyanyi dan menghasilkan suara yang merdu. Hatsune Miku sendiri adalah karakter dengan sosok perempuan yang memiliki penampilan khas manga, sebuah gaya visual dari Jepang untuk merepresentasikan karakter atau tokoh manusia. Manga memiliki ciri khas yang kuat dan melekat pada karakter Hatsune Miku yaitu memiliki mata yang lebar, hidung mancung, bibir kecil, dagu yang lancip serta tubuh yang tinggi dan langsing. Hatsune Miku memiliki banyak penggemar. Bahkan, konser-konsernya di luar Jepang, salah satunya di Kuala Lumpur pada tahun 2017, memiliki penjualan tiket yang sangat cepat dan sold out hanya dalam waktu 60 menit (Yap, 2017).

Media online sempat memberitakan pernikahan seorang pria Jepang bernama Akihiko Kondo dengan Hatsune Miku. Pernikahan ini dilaksanakan sebagaimana pernikahan pada umumnya dengan acara bertukar cincin, melakukan sumpah di depan pemuka agama, dan menandatangani surat nikah. Diberitakan pula bahwa pernikahan tersebut menghabiskan dana sebesar 2 Juta Yen, atau setara dengan 261 juta rupiah. Mungkin sekilas akan tampak biasa saja, namun apabila diceritakan lebih lanjut, Hatsune Miku sendiri adalah sebuah tokoh virtual ${ }^{1}$ yang dibuat oleh perusahaan asal Jepang, Cryptone Future Media.

Hatsune Miku merupakan tokoh virtual yang hidup. la dapat berbicara, menyapa, menjawab pertanyaan, bernyanyi, mengajak bermain, melompat, makan, dan seterusnya. Kegiatan yang sama seperti yang kita lakukan sehari-hari, namun menjadi sebuah

${ }^{1}$ Tidak dalam bentuk aktual. 
simulasi ${ }^{2}$.Hatsune Miku nyata keberadaannya, memiliki bentuk dan visual yang dapat kita lihat secara utuh, namun mereka tidak aktual. Namun, kekuatan komunikasi visual dari bentuk yang dapat dicerna oleh indra memberikan respon positif kepada Akihiko Kondo, sebagai penerima pesan visual (Aw, 2011). Kekuatan bentuk pada akhirnya mampu mencapai realitas palsu. Realitas yang hidup dari tanda-tanda yang lahir sendiri. Realitas tersebut dikonsumsi menjadi kenyataan hingga menjadi sebuah aktivitas fisik seperti sebuah pernikahan merupakan sebuah bentuk kesuksesan konstruksi kode visual menjadi tanda-tanda palsu (Danesi, 2010). Realitas palsu mampu menyamar menjadi kenyataan, hingga mencapai sebuah hiperealitas ${ }^{3}$ (Piliang, 2003).

Tulisan ini menguraikan konstruksi tanda-tanda yang bekerja dari sosok karakter Hatsune Miku dengan menggunakan teori semiotika Rholand Barthes. Tanda diuraikan dan dicari hubungan pemaknaannya antara karakter Hatsune Miku dan Akihiko Kondo. Selain itu analisis hubungan keduanya dilakukan untuk melihat bagaimana tanda-tanda tersebut bekerja dan saling memengaruhi. Kajian ini bertujuan untuk menggali kemungkinan-kemungkinan perluasan bidang desain visual, baik secara konkret maupun secara virtual.

\section{METODE}

Semiotika Rholand Barthes merupakan pengembangan dari semiotika strukturalisme oleh Ferdinand de Saussure. Menurut Saussure, penanda dan petanda seperti dua sisi mata uang (Aart, 2003). Artinya tanda memiliki makna yang melekat langsung pada objek, penanda dan petanda melekat dan saling berikatan. Namun apabila ditarik kebelakang, konsep ini pun berawal dari sebuah konsep abstrak yang merujuk pada objek tertentu. Sebagai contoh, penyebutan kata ikan akan merujuk pada konsep hewan yang memiliki sirip dan hidup di dalam air. Hal ini terjadi karena penamaan kata 'ikan' merujuk kepada sosok hewan tersebut (Sobur, 2011).

Berbeda dengan teori yang dikemukakan oleh Rholand Barthes bahwa penanda dan petanda memiliki pemaknaan lanjutan yaitu konotasi tingkat kedua (Kurniawan, 2001). Penanda pada tingkat awal disebut sebagai denotatif, atau pemaknaan tingkat pertama. Tanda yang terbentuk pada tingkatan ini dimaknai sesuai dengan hubungan arbiter antara penanda dan petanda, hubungan yang sesuai yang mengacu pada objek. Namun ada tingkatan kedua dari keberadaan tanda denotatif yaitu konotatif yang mengalami pembiasan, atau tidak berada pada makna sesungguhnya. Konsep teori semiotika Rholand Bartes dapat ditunjukkan pada gambar berikut ini.

\begin{tabular}{|c|c|}
\hline $\begin{array}{c}\text { 1.Signifier } \\
\text { (penanda) }\end{array}$ & $\begin{array}{c}\text { 2.Signified } \\
\text { (petanda) }\end{array}$ \\
\hline $\begin{array}{c}\text { 3.Denotative sign } \\
\text { (tanda denotatif) (first system) }\end{array}$ \\
\hline $\begin{array}{c}\text { 4.Connotative Signifier } \\
\text { (penanda konotasi) }\end{array}$ & $\begin{array}{c}\text { 5. Connotative Signified } \\
\text { (petanda konotasi) }\end{array}$ \\
\hline \multicolumn{2}{|c|}{ 6onnotative Sign (tanda konotasi) (second system) } \\
\hline
\end{tabular}

Gambar 1. Semiotika Rholand Barthes

Sumber: Konstruksi penulis berdasarkan teori semiotic Rholand Barthes.

\footnotetext{
${ }^{2}$ Penggambaran suatu sistem atau proses dengan peragaan berupa model statistik atau pemeranan (Setiawan, 2020)

${ }^{3}$ Konsep dimana realitas yang dalam konstruksinya tidak bisa dilepaskan dari produksi dan permainan tanda-tanda yang melampaui realitas aslinya (Hyper-sign) (Piliang, 2003).
} 
Di dalam setiap tanda, terdapat penanda dan petanda sebagai dua unsur pembentuknya. Penanda Hatsune Miku dibongkar menjadi bahasa visual untuk memperoleh kode-kode visual yang bekerja di dalamnya. Visualisasi Hatsune Miku yang di dalamnya terdapat kode-kode visual yang tampak, kemudian kode-kode visual tersebut diidentifikasi dan dibaca hubungannya secara semiotik. Setelah itu hasil pembacaan akan dihubungkan dengan kode-kode budaya yang juga berlaku di masyarakat.

\section{HASIL}

Karakter Hatsune Miku merupakan citra visual yang di dalamnya bekerja beberapa tanda. Pertama adalah tanda artifisial, yaitu tanda yang direkayasa melalui teknologi citraan mutakhir (teknologi digital, computer graphic, simulasi), yang tidak mengacu adanya realitas. Tanda yang bekerja dalam karakter Miku mengonstruksi dan menandai dirinya sendiri dalam bentuk bahasa visual "Hatsune Miku". Miku bukan representasi, melainkan hasil konstruksi mekanik dari sebuah ide yang muncul untuk menghadirkan sosok karakter yang cantik dan mampu menyanyi. Konstruksi visual ini mampu menghadirkan kode-kode visual yang menyerupai manusia yaitu rambut berwarna biru yang panjang, mata bulat dan besar, hidung kecil yang lancip, bibir yang tipis, warna kulit putih, memakai baju berwarna putih, menggunakan rok mini berwarna hitam, menggunakan kaos kaki panjang berwarna hitam, serta menggunakan sepatu berwarna hitam. Kode tersebut apabila dikonstruksi menjadi satu bahasa visual akan menghadirkan sosok karakter Miku. Dalam teori signifikasi ${ }^{4}$ oleh Rholand Barthes bahwa konsep tersebut menandai bentuk yang direpresentasikannya. Penanda kode visual tersebut mampu menjadi petanda berupa konsep visual Hatsune Miku.

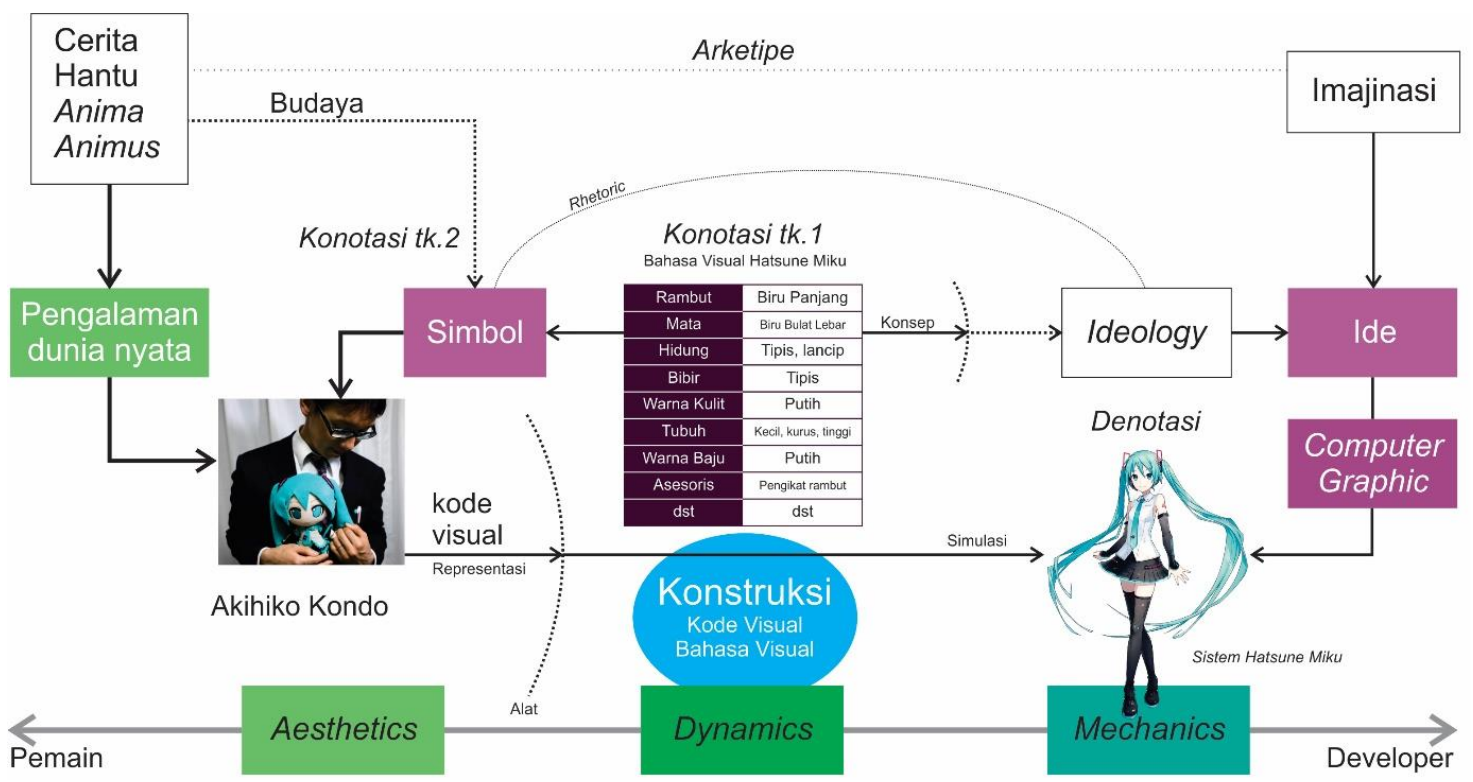

Gambar 2. Konstruksi kode dan bahasa visual Hatsune Miku yang dikonsumsi oleh Akihiko Kondo.

Sumber: Konstruksi penulis berdasarkan teori semiotic Rholand Barthes dan hiperealitas Baudrilard.

\footnotetext{
${ }^{4}$ Menurut Barthes, signification dapat dipahami sebagai sebuah proses yang berupa tindakan, yang mengikat signifier dan signified, dan yang menghasilkan sebuah tanda. Dalam proses tersebut, dua bagian dari sebuah tanda tergantung satu sama lain dalam arti bahwa signified diungkapkan melalui signifier, dan signifier diungkapkan dengan signified. Misalnya, kata "kucing". Ketika kita mengintegrasikan signifier "kucing" dengan signified "hewan berkaki empat yang mengeong", maka bahasa tanda "kucing" pun muncul. Proses ini disebut sebagai signification atau sebuah sistem signifikasi (Amber, 2017).
} 
Akihiko Kondo melihat kode visual Hatsune Miku melalui alat, media digital, melalui kotak hologram yang di letakkan disudut ruangan. Kode visual tersebut mengaktifkan citra sosok Miku sehingga mampu dinikmati secara visual oleh Kondo. Miku dapat bergerak dan berbicara sehingga Kondo merasa bahagia mendengar Miku menyapa setiap pagi saat akan berangkat kerja, saat pulang kerja, maupun saat akan tidur. Dari rutinitas tersebut, Kondo merasa nyaman dengan hadirnya sosok Miku, sehingga tanda yang bekerja dalam diri Kondo sudah mencapai pada tahap konotasi tingkat kedua sehingga tanda sudah dimaknai lebih tinggi lagi. Sosok Miku tidak lagi dimaknai menjadi seorang penyanyi virtual, namun Miku dimaknai sebagai sosok yang mampu memberikan kenyamanan.

Pemaknaan oleh Kondo dipengaruhi oleh pengalamannya di dunia nyata. la menyebutkan bahwa perempuan di dunia nyata, aktual, tidak mampu memahami dirinya. Perempuan Jepang menuntut kehidupan yang baik, sehingga membutuhkan sosok pria yang mampu menghidupinya. Kondo juga tidak menginginkan seorang pacar karena ia merasa tidak populer di kalangan perempuan. Pengalaman ini mengaktifkan pemaknaan konotasi tingkat kedua bahkan sudah pada tahap mitos ${ }^{5}$ bahwa tanda yang bekerja pada konotasi tingkat pertama naik menjadi tataran konotasi tingkat kedua terkait dengan sosok perempuan di dalam pikiran Kondo. Akibatnya, pemaknaan simbol-simbol Miku yang dimaknai oleh kondo adalah sebagai seorang perempuan yang mampu memahami dirinya. Lambat laun terbentuk rasa nyaman yang memuncak di dalam dirinya. Selain itu, pemaknaan simbol tersebut juga terjadi karena alam bawah sadar Kondo untuk mencintai perempuan. Anima ${ }^{6}$ yang bekerja di dalam dirinya harus tetap terfasilitasi dengan baik, sehingga keputusan untuk menikahi Miku merupakan hal yang ideal untuknya.

\section{BAHASAN}

Untuk membedah hubungan ideal dan aktual antara Miku dan Akihiko Kondo digunakan bagan yang dibuat oleh Rob Shield. Bagan tersebut menjelaskan pergerakan antara dunia virtual dengan dunia konkret. Bagan ini juga menjelaskan bagaimana dunia energi dan dunia fisik secara nyata mampu berjalan berdampingan. Dua dunia ini dipisahkan oleh sebuah alat seperti handphone, laptop, console, $V R$ dsb., namun masing-masing dapat hidup untuk menuju sesuatu tujuan di masa depan yaitu kemungkinan (Shield, 2011).

Hatsune Miku merupakan sosok virtual di dalam dunia energi dari sebuah ketiadaan. Sesuatu yang tidak ada, tidak berbentuk, tidak terpikir, dan abstrak. "Miku" adalah sebuah nama yang belum terdefinisi, namun, mungkin harus menggambarkan sosok perempuan yang cantik dan dicintai. Bagaimana sosok ini mampu bangkit dan hidup, ini merupakan sebuah bentuk yang harus ada dari sebuah ketiadaan. Sebuah bentuk konotasi pikiran, sebuah konsep akan bentuk, dari sebuah definisi kata "cantik" yang diterjemahkan menjadi sebuah bentuk yang konkret, sebuah desain, visual, dan virtual; sehingga konsep bentuk ini mampu didefinisikan menjadi simbol, yaitu sebuah kesepakatan tentang sosok wanita yang cantik. Simbol ini didefinisikan menjadi kode-kode visual yang mengikuti paradigma ${ }^{7}$ kecantikan dalam dunia fisik untuk diadopsi ke dalam dunia energi. Akibatnya, sosok Hatsune Miku tampak secara denotatif dalam ranah virtual.

Konstruksi tanda Hatsune Miku merupakan kode-kode visual yang diyakini oleh perusahaan pembuatnya sebagai seorang wanita, memiliki makna kecantikan dan bersuara

\footnotetext{
${ }^{5}$ Dalam semiotika Rholand Barthes Mitos hadir dalam tataran kedua atau konotasi tingkat kedua sebagai sarana mendistorsikan fakta sehingga masyarakat akan menerima begitu saja tanpa perlawanan.

${ }^{6}$ Penjelmaan sifat perempuan dalam rupa manusia, sifat perempuan yang terdapat dalam alam nirsadar laki-laki.

${ }^{7}$ Hubungan tanda yang bersifat horizontal, yaitu tanda yang mampu menggantikan tanda yang lain.
} 
merdu sebagai komoditasnya. Hatsune Miku di dalam dunia energi merupakan sebuah simulakrum, yaitu sebuah simulasi yang menandai dirinya sendiri. Tanda yang hidup dan memaknai dirinya sendiri.

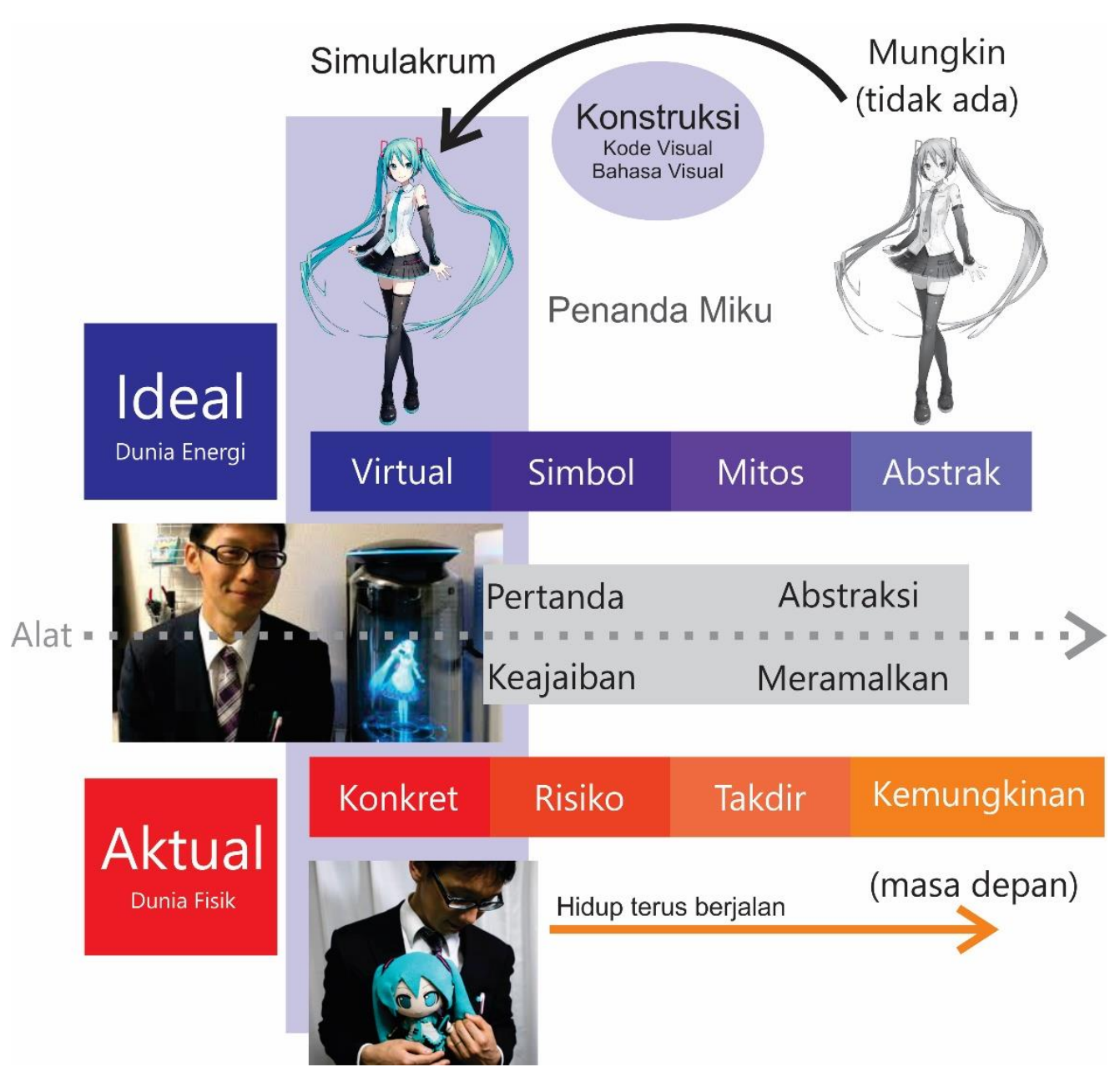

Gambar 3. Pergerakan konstruksi visual Hatsune Miku menjadi simulakrum dan hubungannya dengan dunia fisik.

Sumber: Konstruksi penulis berdasarkan konsep Rob Shield.

Di dunia fisik Akihiko Kondo hanya mampu melihat sosok Hatsune Miku secara visual, melalui alat yang mampu menunjukkan simulasi yaitu berupa kotak hologram yang diletakkan di atas meja. Kotak hologram inilah yang mampu memproyeksikan kode-kode ${ }^{8}$ visual Hatsune Miku. Selain itu, kotak tersebut juga memiliki kemampuan untuk menghasilkan suara seorang wanita.

Melalui penanda ${ }^{9}$, Hatsune Miku harus diterjemahkan menjadi representasi fisik apabila Kondo ingin meraba dan merasakan kehadirannya secara konkret. Sebagai contoh, representasi fisik, bentuk petanda ${ }^{10}$ dari bentuk virtual, tersebut bisa jadi boneka, maupun guling yang merepresentasikan Hatsune Miku, tetapi, tidak benar-benar hadir dalam wujud

\footnotetext{
${ }^{8}$ Cara pengombinasian tanda yang disepakati secara sosial, untuk memungkinkan satu pesan disampaikan dari seseorang ke orang lainnya.

${ }^{9}$ Disebut juga signifier merupakan konsep awal tanda yang diangkat oleh Ferdinand de Saussure tentang citraan atau kesan mental dari sesuatu yang bersifat verbal atau visual, seperti tulisan, suara atau benda.

${ }^{10}$ Disebut juga signified merupakan konsep abstrak atau makna yang dihasilkan oleh penanda.
} 
manusia hidup. Dalam kenyataan, Kondo tetap harus menghadapi kemungkinan hidup di masa depan, menghadapi risiko, baik fisik maupun mental serta berserah kepada takdir yang membawanya kepada kemungkinan-kemungkinan yang tidak dapat ia pastikan.

Hiperealitas dengan hadirnya Miku dan Naeyon dijelaskan dalam konsep yang diusung oleh Baudrillard tentang simulasi, hubungan antara tanda, citra dan realitas. Citra, sebagai sebuah konstruksi visual yang tampak oleh indra, tetapi tidak memiliki eksistensi substantial digolongkan menjadi 4 macam. Pertama, citra yang yang menggambarkan realitas atau benarbenar menunjukkan bentuk asli. Kedua, citra yang memutarbalikkan realitas. Dalam hal ini, citra menutupi bentuk asli. la tidak jujur dengan apa yang dicitrakan. Ketiga adalah citra yang menopengi ketiadaan realitas. Citra bertindak untuk menunjukkan hal yang tidak tampak. Keempat, citra yang menandai dirinya sendiri. Dalam hal ini, citra tidak mengacu kepada apapun. la hidup di luar realitas sehingga tanda akan menandai dirinya sendiri, atau disebut pure simulakrum. Menurut Baudrillard, tanda-tanda dalam hiperealitas yang berwujud dan menjadi hyper-sign dapat dikonstruksi menjadi komoditi kapitalis. Sehingga, tanda dituntut memiliki pengemasan, pesona, kejutan, provokasi dan daya tarik (Piliang, 2003).

\section{SIMPULAN}

Penciptaan kenyataan dalam dunia ideal saat ini memang sangat menarik untuk dikaji. Perkembangan teknologi yang sangat pesat mampu menembus batas-batas ruang aktual dan ideal menjadi tidak jelas dan campur aduk. Tanda-tanda visual, melalui penggalian kode-kode mampu mengonstruksi realitas baru dalam dunia virtual. Realitas baru ini hidup dan menyapa manusia di dunia aktual untuk berinterkasi dan melakukan kegiatan yang natural.

Makna-makna yang terbentuk dalam dunia virtual mampu dibawa ke ranah aktual melalui makna tipuan yang secara terus menerus berkembang. Makna perempuan yang baik dan perhatian dari sosok Hatsune Miku merupakan makna-makna tipuan yang mampu menaturalisasi diri apabila manusia terus menerus mendengungkan maknanya. Mitos yang berkembang akan dihadapkan dengan mitos dunia virtual yang lahir dari sosok Hatsune Miku, yakni bahwa sosok virtual memiliki perhatian yang lebih dan tidak menuntut.

Selanjutnya, tanda yang mampu dikonstruksi secara virtual dan diyakini menjadi tanda sebenarnya (propersign) akan mampu menaturalisasi diri menjadi objek yang hidup, walaupun secara virtual. Objek ini dianggap menjadi representasi sehingga kejujuran makna tanda dari objek tersebut mampu menimbulkan kepercayaan tersendiri. Tanda palsu yang terus menandai dirinya sendiri.

Tanda-tanda yang menaturalisasi dirinya sendiri saat ini maupun di masa yang akan datang bisa jadi menjadi mitos-mitos yang diyakini sebagai tanda yang benar. Aktivitas pernikahan dengan Avatar, maupun hidupnya Avatar dari orang yang meninggal bisa menjadi hal yang biasa, menjadi budaya digital yang natural karena pikiran manusia yang semakin bisa dalam mengonsumsi tanda-tanda. Manusia semakin menuntut kepuasan visual sehingga menjadi kebutuhan, dan tentu saja kebutuhan akan menumbuhkan produksi tanda yang semakin tidak terbatas. Permainan visual tiada akhir.

\section{PUSTAKA ACUAN}

Aart, Van Zoest, 2003, Semantik: Pengantar studi tentang makna, Yogyakarta: Tiara wacana. Aw, S, 2011, Komunikasi interpersonal, Yogyakarta: Graha Ilmu.

Amber, 2017, Juni 8, Teori semiotika Roland Barthes. Retrieved from pakarkomuikasi.com: https://pakarkomunikasi.com/teori-semiotika-roland-barthes

Danesi, M, 2010, Pesan, tanda, makna: Buku teks dasar mengenai semiotika dan teori komunikasi, Yogyakarta: Jalasutra.

Kurniawan, 2001, Semiologi Roland Barthes, Magelang: Yayasan Indonesiatera.

Piliang, YA, 2003, Hipersemiotika, tafsir cultural studies atas matinya makna. Yogyakarta: Jalasutra. 
Setiawan, E, 2020, Februari 17, Kata dasar simulasi. Retrieved from Kamus Besar Bahasa Indonesia (KBBI): https://kbbi.web.id/simulasi

Shield, R, 2011, Virtual, sebagai pengantar komprehensif. Yogyakarta: Jalasutra.

Sobur, A, 2009, Semiotika komunikasi, Bandung: Remaja Rosdakarya.

Yap, N, 2017, Oktober 8, The Hyped Geek. Retrieved from THG: http://thehypedgeek.com/hatsune-miku-malaysia-tickets-sold-within-hour-opening/

\section{BIBLIOGRAFI}

Abdullatif, 2018, Februari, Apa yang dimaksud dengan Dunia Maya atau Cyberspace? Retrieved from dictio.id: https://www.dictio.id/t/apa-yang-dimaksud-dengan-duniamaya-atau-cyberspace/15151

Ambar, 2019, Agustus 30, Komunikasi visual: 5 fungsi green screen dalam pembuatan film. Retrieved from PakarKomunikasi.com: https://pakarkomunikasi.com/fungsi-greenscreen-dalam-pembuatan-film

Franedya, R, 2019, May 16, CNBC Indonesia. Retrieved from CNBC Indonesia web site: https://www.cnbcindonesia.com/tech/20190516191935-37-73041/survei-penggunainternet-di-ri-tembus-17117-juta-jiwa

Rou, 2015, April 08, detikInet. Retrieved from https://inet.detik.com/: https://inet.detik.com/games-news/d-2880848/tomb-raider-pecahkan-rekorpenjualan-game

Suniarini, K, Sukarini, NW, \& Budiasa, IG, 2017, Semiotic study on colour terms in "Aquamarine" Film, Journal Humas, 18(2), 386-395.

Usmanda, Y, 2018, September 26, Kincir. Retrieved from kincir.com: https://www.kincir.com/game/console-game/5-fakta-lara-croft 